\title{
Inaccuracies in the recently published review on mirabegron
}

\author{
Emad Siddiqui
}

Received: 24 October 2013 / Accepted: 4 November 2013 / Published online: 7 December 2013

(C) The Author(s) 2013. This article is published with open access at Springerlink.com

\section{Dear Editor}

I read with interest the recently published review article by Caremel et al. [1] titled "What do we know and not know about mirabegron, a novel $\beta 3$ agonist, in the treatment of overactive bladder?" Whereas it is generally an accurate and well-balanced article, I note a few inaccuracies. I would like to point out that mirabegron was approved in Japan in July 2011 at a usual adult dose of $50 \mathrm{mg} /$ day [2], not $25 \mathrm{mg} /$ day, approved in 2010, as stated in the article. Furthermore, the article states that "long-term adverse events have not yet been fully investigated"; however, the authors failed to incorporate data from a 1-year safety study [3] published in November 2012, well in advance of publication of their review. Further safety data will also be published in the near future, including a recently completed Japanese phase IV study (NCT01745094), which the article's authors noted was not yet available.

Conflict of interest statement Emad Siddiqui is a full-time employee of Astellas Pharma Europe Ltd, the company responsible for the development and marketing of mirabegron. Editorial assistance, supported financially by Astellas Pharma Inc, was provided by Paul Lane of Envision Scientific Solutions during the preparation of this letter.

Open Access This article is distributed under the terms of the Creative Commons Attribution License which permits any use, distribution, and reproduction in any medium, provided the original author(s) and the source are credited.

\section{References}

1. Caremel R, Loutochin O, Corcos J (2013) What do we know and not know about mirabegron, a novel $\beta 3$ agonist, in the treatment of overactive bladder? Int Urogynecol J. doi:10.1007/s00192-013-2161-4

2. Astellas Pharma Inc (2011) http://www.astellas.com/en/corporate/ news/pdf/110915_en_1.pdf. Accessed 17 October 2013

3. Chapple CR, Kaplan SA, Mitcheson D, Klecka J, Cummings J, Drogendijk T, Dorrepaal C, Martin N (2013) Randomized doubleblind, active-controlled phase 3 study to assess 12-month safety and efficacy of mirabegron, a $\beta(3)$-adrenoceptor agonist, in overactive bladder. Eur Urol 63:296-305
E. Siddiqui $(\square)$

Astellas Pharma Europe Ltd., Chertsey, UK

e-mail: Emad.Siddiqui@astellas.com 